\title{
Web based Information system for selling spare parts and custom bicycle frames (Case Study Of The Surabaya Minion Shop)
}

\section{Sistem Informasi Penjualan Spare part dan Custom Rangka Sepeda Mini Berbasis Web (Studi Kasus Toko Minion Surabaya)}

\author{
Muhammad Hendra Octaviano ${ }^{1}$, Arif Senja Fitrani ${ }^{2}$ \\ \{muhammad.octaviano123@gmail.com¹, asfjim@umsida.ac.id $\left.{ }^{2}\right\}$
}

Universitas Muhammadiyah Sidoarjo, Indonesia ${ }^{1}$, Universitas Muhammadiyah Sidoarjo, Indonesia ${ }^{2}$

\begin{abstract}
The purpose of this research is to design and produce an Online Shop application that is a Web that can provide information on goods data related to the sale of spare parts and custom frames that they are looking for. The research method used is the waterfall method, while the techniques for data collection use observation and interview techniques. The spare part data is obtained from visiting from shop to shop and the shop itself. The result of this research is to make it easier for customers to find the spare parts they want and to make more and more bicycle enthusiasts, especially onthel mini bikes, use them.
\end{abstract}

Keywords - sparepart; minion bike; misu store

\begin{abstract}
Abstrak. Tujuan dari penelitian ini adalah merancang dan menghasilkan sebuah aplikasi Toko Online yangbersifat Web yang dapat memberikan informasi data barang terkait penjualan spare part dan custom rangka yang sedang mereka cari. Metode penelitian yang digunakan ialah metode waterfall, sedangkan tehnik untuk pengumpulan datanya menggunakan tehnik observasi dan wawancara.Untuk data spare partnya didapatkan dari mengunjungi dari toko ke toko dan tokonya sendiri. Hasil dari penelitian ini adalah membuat pelanggan agar memudahkan mencari sparepart yang diinginkannya dan membuat para peminat sepeda khususnya sepeda mini onthel ini semakin banyak yang memakainya.
\end{abstract}

Kata Kunci - onderdil; sepeda minion; toko misu.

\section{PENDAHULUAN}

Di musim sekarang ini sangat banyak peminat sepeda, khsusnya sepeda minion ini dari kalangan masyarakat jika dibaca atau terdengar kata tersebut langsung kebayang-bayang sosok karakter animasi yang sangat terkenal dikalangan masyarakat berwarna kuning, bermata besar dan kadangkala berkacamata. Namun bagi kalangan pesepeda di tanah air ini kata Minion adalah sebutan bagi pecinta sepeda mini onthel di Indonesia.

Sejarah Sepeda Minion adalah sepeda mini onthel yang berbentuk mungil atau kecil yang berukuran 20, untuk dikatakan seperti minion atau mini onthel sendiri hanya bisa dikatakan dengan ukuran 20 kebawah dan untuk ukuran diatasnya 20 berarti tidak memiliki unsur minion atau mini onthel. Sepeda mini onthel kini sudah ada sejak tahun 50 an - 70 an kemudian sepeda tersebut terasingkan atau punah, kemudian di era tahun 90 an. Sepeda mini onthel mulai meningkat lagi sampai tahun sekarang yaitu tahun 2021, di tahun 2021 ini justru peminat dari sepeda mini onthel sendiri benar-benar sangat banyak sekali dan peminatnya sendiri sangat bermacam-macam contohnya : mulai dari anak-anak usia 14 tahun hingga 73 tahun. Sepeda mini onthel sekarang tambah hari tambah banyak peminat sepedanya, malah setiap kota juga semakin banyak peminatnya, khususnya di daerah Surabaya sendiri juga banyak peminatnya dan di Surabaya sekarang semakin hari semakin bertambah, maka terdapat Komunitaskomunitas yang ada di Surabaya sendiri Contohnya : Komet's, Minion Surabaya, Osaka, MBC (Minitrek Bike Community), MSC

( Minitrack Surabaya City), Mars (Minitrek ARek Surabaya) dan masih banyak lagi di tahun tahun berikutnya.

Identifikasi masalah yang peneliti peroleh yakni kesulitannya bagi komuunitas yang akan melakukan suatu kegiatan usaha agar mencapai tujuannya untuk membantu para peminat sepeda mini onthel ini agar mudah mencari spare part maupun custom an rangka sepedanya, pada saat ini hanya ada beberapa komunitas sepeda yang menjual suatu dagangan atau barangnya. Pada aplikasi misu store terdapat bermacam-macam barang yang dijual dan terdapat menu kegiatan komunitas yang bertujuan untuk dipublikasikan mengenai acara-acara yang ada didalam komunitas tersebut, daftar barang penjualan yang dijual : spare part/onderdil sepeda, aksesoris, pakaian dan custom rangka yang berbasis web ini, informasi mengenai penjualan tersebut dapat membantu para pegoweser khususnya minion atau berukuran 20" supaya tidak kebingungan mencari barangbarang yang akan dibelinya. 
Penelitian yang sama telah dilakukan oleh Amrullah, pada penelitiannya di toko sepeda sumber berkat di Jakarta telah menciptakan sebuah sistem informasi penjualan berbasis web dan sistem tersebut digunakan agar mempermudah Memasarkan berbagai produk dan harga dalam bentuk price list yang akan memberikan gambaran tentang produk sepeda dan spare part secara lebih mendetail.

Informasi adalah suatu data yang dapat diolah menjadi bentuk yang sangat berguna dan lebih berarti bagi yang menerimanya, sedangkan data merupakan sumber informasi yang bisa digambarkan suatu kejadian yang nyata [1].

Berdasarkan itulah peneliti memiliki tujuan untuk menerapkan kemudahan memperoleh informasi tersebut tidak hanya pada benda spare part saja, namun juga ada custom rangka, aksesoris dan dengan tujuan sekali lagi yakni untuk mempermudah dan mengefesienkan waktu untuk mencari spare partnya baik pegoweser atau dari komunitas. Untuk itu peneliti memulai menggagas sebuah ide penelitian yang berjudul "Sistem Informasi Penjualan Spare part dan Custom Rangka Sepeda Mini Berbasis Web”.

\section{METODE}

\section{A. Objek Penelitian}

Objek pada penelitian ini dilaksanakan di toko minion surabaya yang berada di Surabaya, pada sistem yang dibuat tidaklah sangat jauh dari kondisi maupun keadaan yang sesungguhnya. Oleh karena itu peneliti membuat sebuah sistem informasi penjualan melalui online yang sangat berguna dan permasalahan yang ada. Dengan ini menyatakan bahwa media jual beli secara online sangat dibutuhkan dikalangan masyarakat.

\section{B. Analisa Perangkat Lunak}

1) Kebutuhan Perangkat Lunak

Pada analisis pengembangan web misu store ini, didapatkan beberapah kebutuhan fungsionalnya yang dapat di implementasikan, yakni:

a. Kebutuhan Fungsional

Kebutuhan fungsional yang terdapat pada platform website yang dapat diimplementasikan yaitu seperti : (1) Aplikasi website dapat menyediakan tempat untuk mencari sparepart maupun custom rangka sepeda. (2) Aplikasi website dapat dengan mudah dipahami. (3) Aplikasi website dapat menyimpan foto-foto dari kegiatan suatu acara di komunitas.

b. Kebutuhan Non-fungsional

Kebutuhan non-fungsional selanjutnya yang dapat diimplementasikan pada aplikasi website yaitu terdapat tampilan yang dibuat untuk memudahkan baik pada pengguna perangkat android maupun admin pada aplikasi website.

2) Lingkungan Implementasi Perangkat Lunak

Pada pengembangan aplikasi website misu store ini, tentu menggunakan beberapa dari suatu perangkat lunak maupun perangkat keras yang digunakan. Pada pengembangan aplikasi ini, peneliti menggunakan perangkat lunak seperti :

> Sistem operasi windows 10. (2) Peramban google chrome. (3) Sublime Text. (4) XAMPP. Adapun pada perangkat keras yang digunakan peneliti, seperti : (1) Laptop dengan spesifikasi : (a) Processor Intel® Pentium® CPU 2020M @ 2.40Ghz. (b) Memori Ram sebesar 6Gb. (c) HDD berkapasitas 500Gb.

$>$ MySQL (My Structure Query Languange) adalah salah satu jenis perangkat lunak yang digunakan untuk membangun data base server yang sangat terkenal dan banyak digunakan untuk membangun aplikasi web yang menggunakan database sebagai sumber dan pengelolaan datanya" [2].

$>$ Bahwa Cascading Style Sheet yang sering dipanggil CSS ini mempunyai peranan yang sangat penting diHTML. Dalam sebuah penulisan dan penampilan juga dapat membuat HTML sendiri menjadi lebih bagus dan indah [3].

$>$ SQL atau kepanjangan(Structure Query Language) adalah suatu aplikasi komputer yang menuju pada konsep Relational Database Management Systems (RDBMS), terdapat suatu struktur bahasa yang sudah ada dalam membangun basis datanya" [4]. 
Procedia of Engineering and Life Science Vol. 1. No. 2 Juni 2021

Seminar Nasional \& Call Paper Fakultas Sains dan Teknologi (SENASAINS 2nd)

Universitas Muhammadiyah Sidoarjo

\section{Metode Pengembangan Aplikasi}

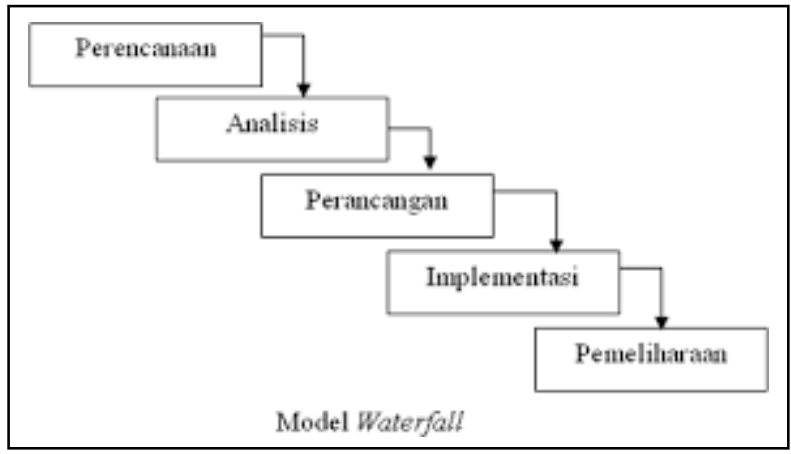

Gambar 1. Model Waterfall

Aplikasi Misu Store ini juga menggunakan metode pembangunan yang sama dengan penelitian terdahulunya yakni metode waterfall, bahwa metode waterfall ialah bermodel klasik namun bersifat sistematis, untuk pembangunan aplikasinya menggunakan metode ini agar dapat dilakukan dengan berurutan seperti dijelaskan pada Gambar 1.

\section{HASIL DAN PEMBAHASAN}

\section{A. Diagram alir penelitian dengan simbol flowchart}

Terdapat tahapan - tahapan yang akan dilakukan untuk melanjutkan penelitian ini dengan menyusun alir penelitian agar dapat berjalan secara teratur. Bagan alir (flowchart) secara keseluruhannya adalah pandangan dalam bentuk bagan alur dari algoritma di suatu program yang bisa dikatakan alur program [5]. Berikut gambar alir penelitian :

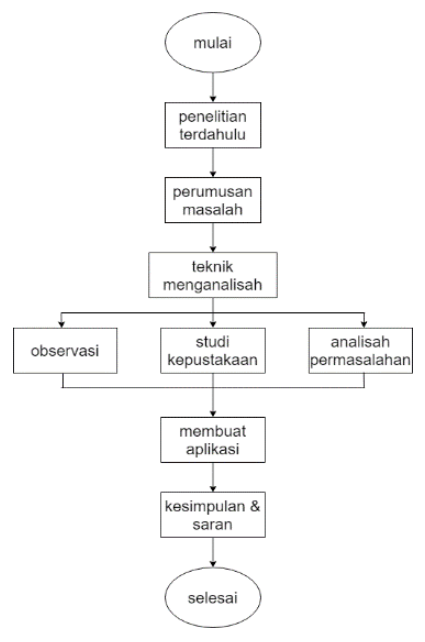

Gambar 2. Alir penelitian

Penjelasan :

1. Pertama mencari penelitian terdahulu agar mengerti permasalahan yang akan diteliti.

2. Lalu memikirkan rumusan masalah yang dibuat untuk memfokuskan penelitian.

3. Kemudian melakukan teknik menganailisah agar hasil penelitian mendapatkan hasil yang maksimal. Teknik menganalisah yang digunakan ada 3 yaitu observasi (di penelitian ini menggunakan metode pengamatan), Studi kepustakaan dengan mencari referensi-referensi yang sudah ada sebelumnya, dan Analisah permasalahan untuk menentukan batasan masalah.

4. Jika sudah mendapatkan data-datanya langsung membuat aplikasi penelitiannya. Bila sudah selesai maka tahap selanjutnya membuat kesimpulan dan saran untuk aplikasi yang dibuat tadi tentang kelebihan dan kekurangannya. 
Procedia of Engineering and Life Science Vol. 1. No. 2 Juni 2021

Seminar Nasional \& Call Paper Fakultas Sains dan Teknologi (SENASAINS 2 ${ }^{\text {nd }}$ )

Universitas Muhammadiyah Sidoarjo

\section{B. Desain Sistem (UML)}

pemodelan sesungguhnya digunakan untuk penyederhanaan permasalahan-permasalahan yang kompleks sedemikian rupa sehingga lebih mudah dipelajari dan dipahami [6].

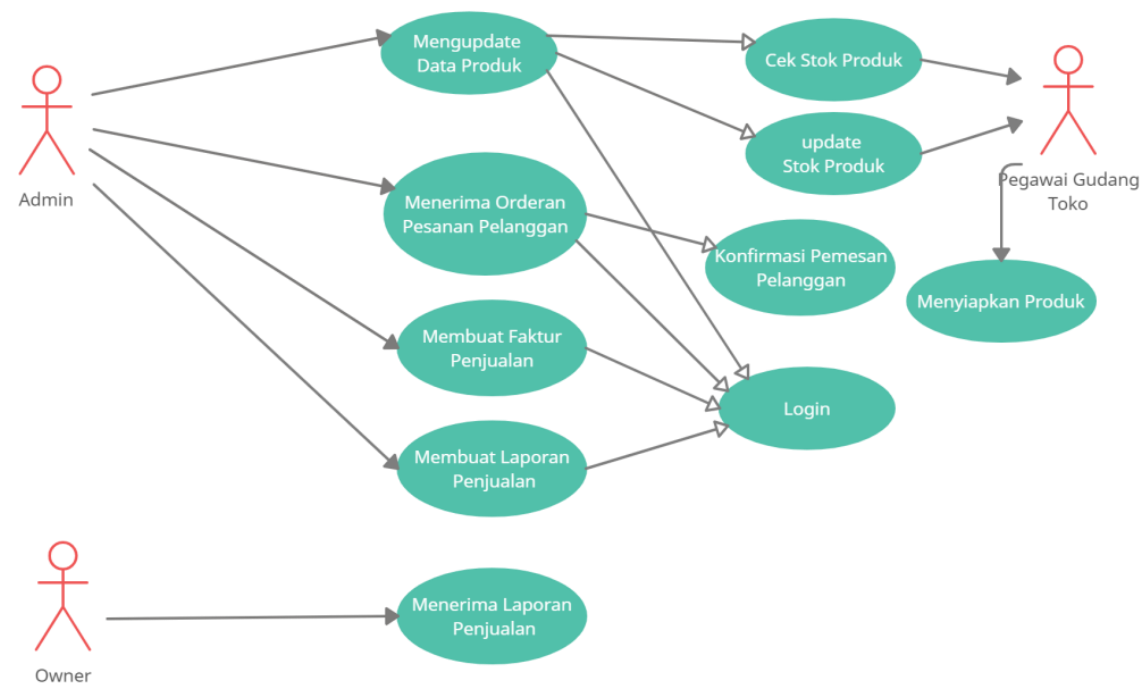

Gambar 3. Use Case Admin

Terkait Use Case Admin pada gambar 3 tersebut menjelaskan bahwa admin bisa mengupdate produk, mengedit dan menghapu. Admin dapat menerima orderan pesanan dari pelanggan, membuat faktur penjualan dan membuat laporan penjualan.

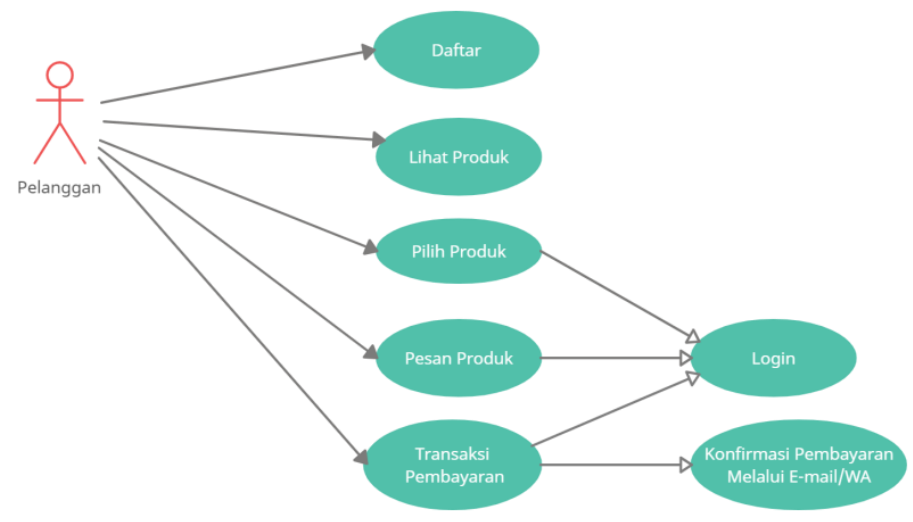

Gambar 4. Use Case Pelanggan Order

Pada Use Case Pelanggan diatas menjelaskan bahwa pelanggan harus mendaftar terlebih dahulu agar bisa login, pilih produk yang diinginkan dan agar bisa melakukan transaksi pembayaran.

\section{Aktiviti Diagram}

Activity diagram dibuat berdasarkan aliran dasar yang di airkan secara alternatif pada skenario use case diagram [7]. 


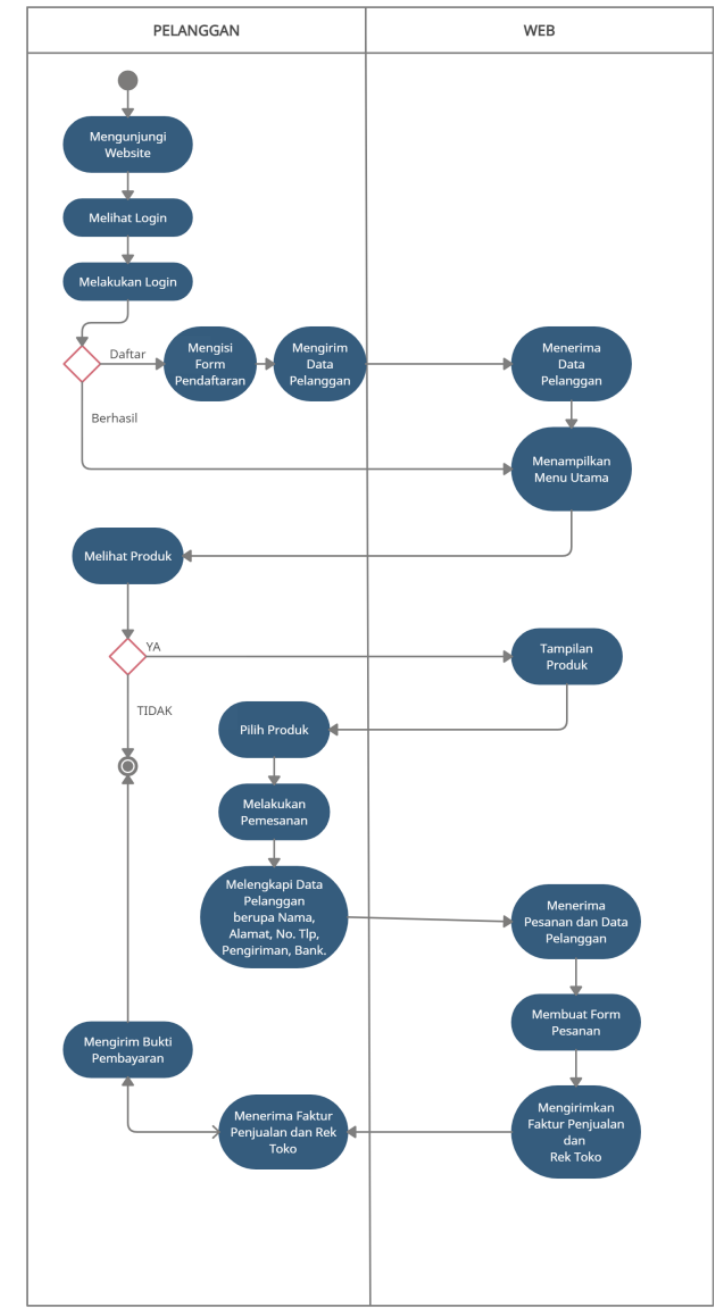

Gambar 5. Aktiviti Diagram Pemesanan Produk

Terkait Aktiviti Diagram pada gambar 5 tersebut menjelaskan bahwa alur dari pemesanan produk sampai pembayaran.

\section{Implementasi Antarmuka Perangkat Lunak}

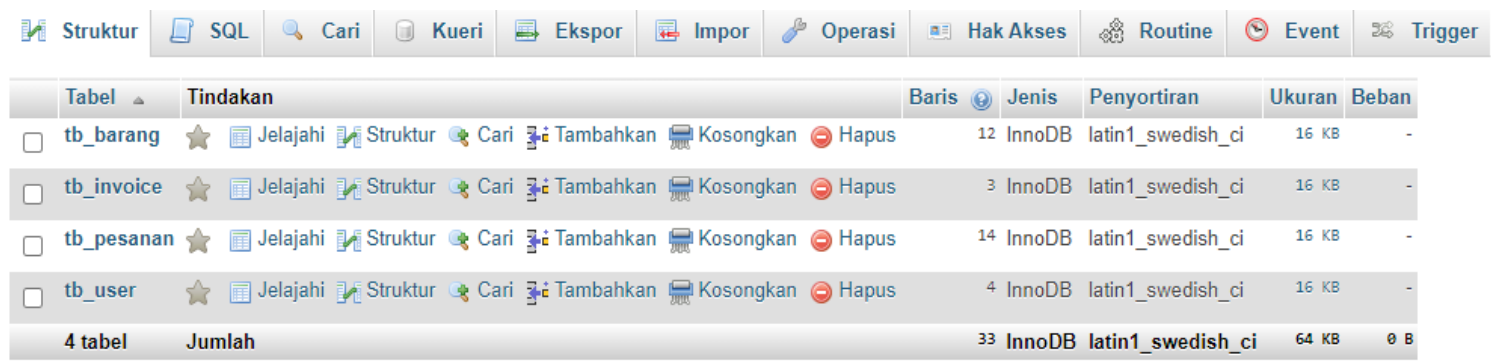

Gambar 6. Tampilan Data Base Toko Online

Pada tampilan database diatas ada beberapa tabel yaitu tabel barang, tabel invoice, tabel pesanan dan tabel user. Basis Data terdiri dari 2 kata, yaitu Basis dan Data. Basis merupakan kurang lebihnya dapat diartikan sebagai wadah atau gudang, tempat untuk bersarang/berkumpul [8]. Saling terhubung antara database dengan entity Relationship diagram merupakan suatu teknik yang dapat digunakan untuk memodelkan kebutuhkan data dari organisasi, maupun system analys dalam persyaratan proyek ke dalam pengembangan system [9].

Antarmuka perangkat lunak pada platform website terdapat implementasi pengembangan antarmuka suatu perangkat lunak pada platform website didapatkan beberapah halaman yang nantinya akan dimudahkan dan dapat 
Procedia of Engineering and Life Science Vol. 1. No. 2 Juni 2021

Seminar Nasional \& Call Paper Fakultas Sains dan Teknologi (SENASAINS $2^{\text {nd }}$ )

Universitas Muhammadiyah Sidoarjo

menunjang pada pengelolaan terkait penjualan online [10]. Diantaranya ialah :

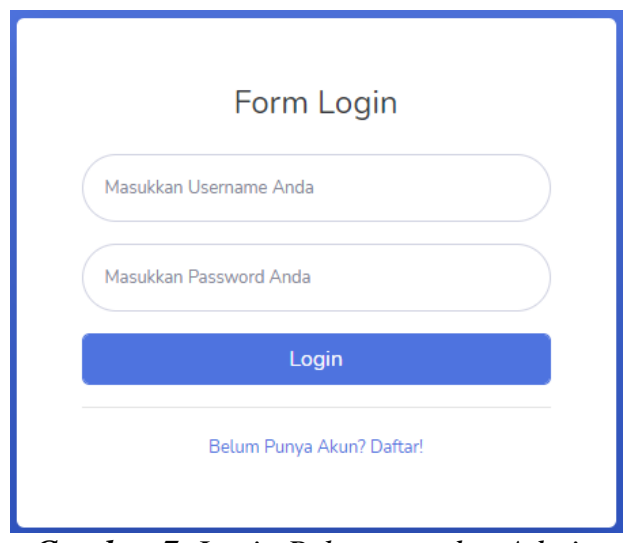

Gambar 7. Login Pelanggan dan Admin

Terkait Login pada gambar diatas, diantaranya penampilan menu Form login pelanggan dan Admin memang sama. Tetapi yang membedakan user dan admin pada databasenya, yang dimaksud berbeda ialah user dengan role id 2 sedangkan admin dengan role id 1 .
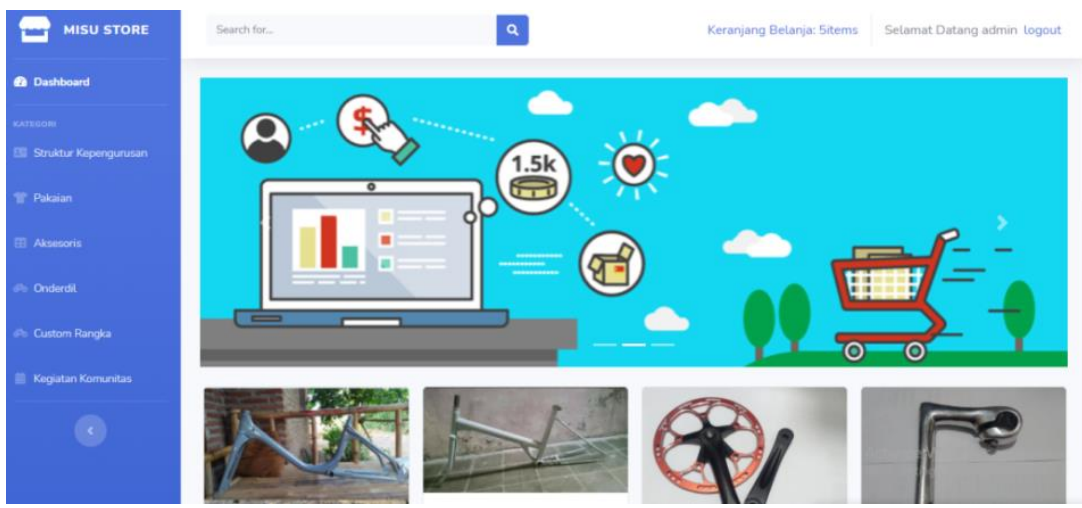

Gambar 8. Tampilan Halaman Utama User

Halaman utama user yang seperti pada Gambar 7 tersebut memiliki tampilan menu - menu yang diantaranya : menu struktur kepengurusan yaitu didalamnya terdapat profil kepengurusan dari Komunitas Misu, kemudian menu pakaian yang dimana menu tersebut menjual produk pakaian, aksesoris yang dimaksud adalah aksesoris dari produk dari komunitas Misu yaitu masker, manset tangan dan emblem/logo, menu onderdil yaitu terdapat produk spare part sepeda contohnya : stem, stir, sadel, crank, rem, kemudia menu custom rangka yang didalamnya terdapat custom-an rangka sepeda mini dan menu kegiatan komunitas ini dibuat untuk mempublikasi suatu acara gowes bareng bersama komunitas lainnya.
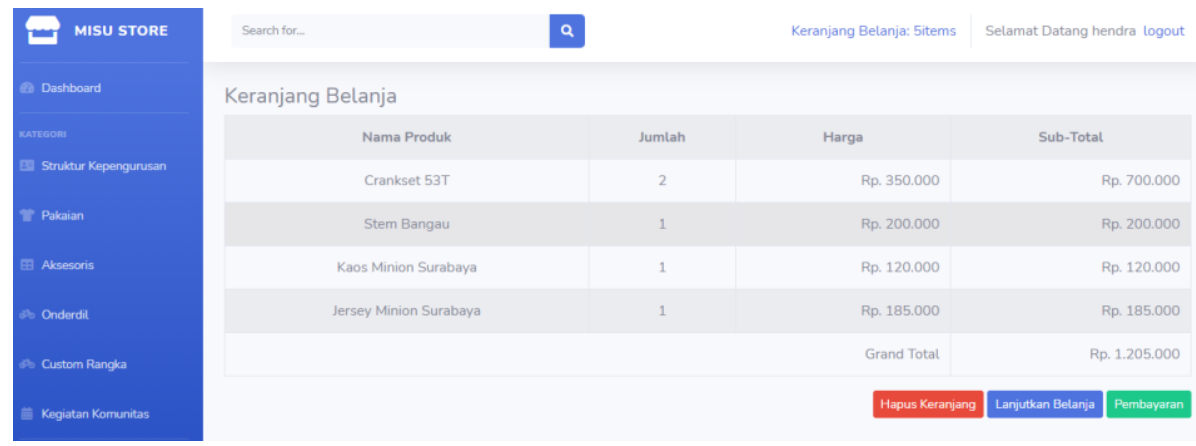

Gambar 9. Tampilan Halaman Keranjang Belanja

Pada halaman keranjang Belanja yang terdapat di gambar 8 tersebut menjelaskan bahwa user/pelanggan memesan suatu barang yang terdapat di toko, di tampilan tersebut ada menu hapus keranjang yang berfungsi untuk 
apabila pelangan salah pilih produk atau membatalkan pemesanan maka boleh mengklik menu hapus keranjang, menu lanjutkan belanja tersebut menjelaskan apabila pelanggan mau melanjutkan berbelanja lagi dan menu terakhir adalah pembayaran yaitu apabila pelanggan sudah memesan produk dan akan membeli maka selanjutnya mengeklik menu pembayaran dan mengisi data diri pelanggan.

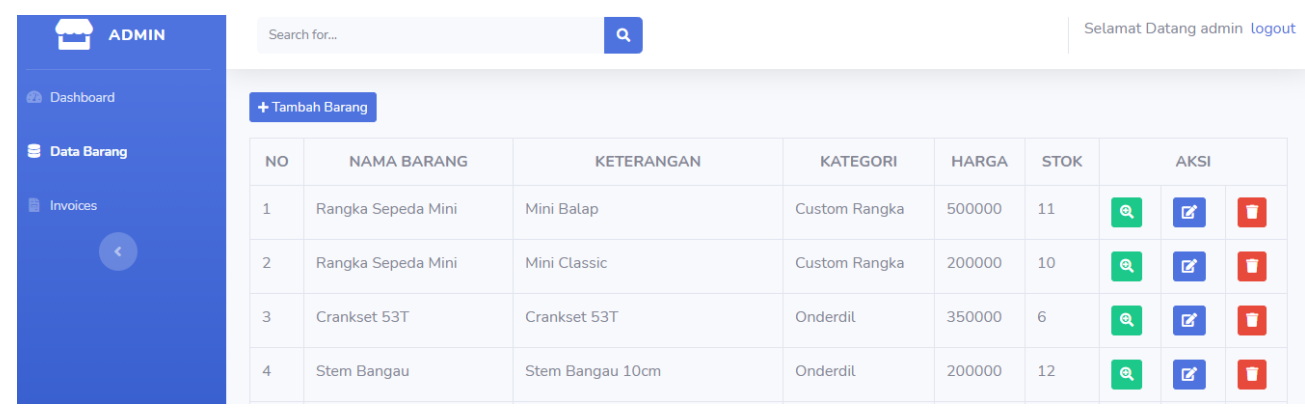

Gambar 10. Tampilan Halaman Data Barang dan Tambah Barang pada Admin

Halaman data barang admin yaitu memiliki fungsi menambahkan produk yang akan dijual dan muncul di menu halaman user. Data barang tersebut memiliki menu aksi yang diantaranya menu detail, menu edit dan menu hapus.
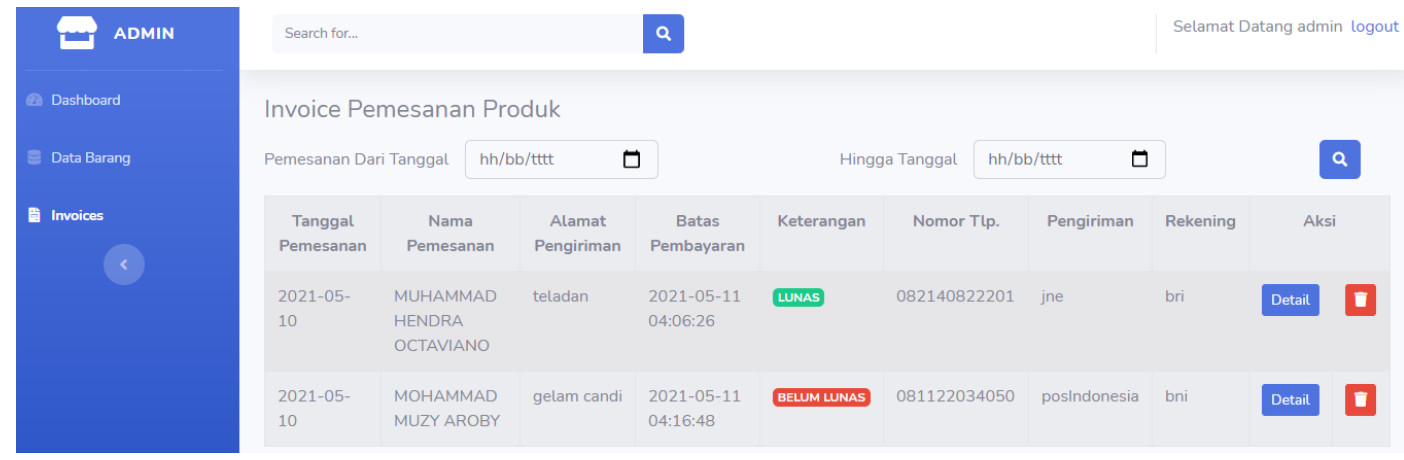

Gambar 11. Tampilan Halaman Invoice pada Admin

Pada menu halaman invoice berfungsi sebagai pemesanan produk pada pelanggan yang akan melakukan pembelian pada produk yang dijual.

\section{KESIMPULAN}

Berdasarkan hasil dari analisis dan pengimplementasian diatas bahwa Aplikasi Misu Store Berbasis Web tersebut memiliki kesimpulan sebagai berikut : (1) Aplikasi tersebut baik pada tampilan websitenya telah dikembangkan dengan sesuai kemampuan, harapan dari peneliti, baik dari segi fungsional maupun non-fungsional. (2) Pada Aplikasi Misu Store dapat membantu para pecinta sepeda agar dimudahkan dalam mencari onderdil/spare part dari sepedanya dan dapat melakukan mengcustom rangka sepeda terkhususkan mini berukuran 20". (3) Aplikasi Misu Store juga mempublikasikan berupa foto suatu acara dan kegiatan komunitas yang menyelenggarakan suatu acara.

Adapun saran yang dimaksudkan untuk pengembangan lebih lanjut mengenai Aplikasi Misu Store Berbasis Web ini sebagai berikut : (1) Penambahan fitur akun yang berfungsi untuk komunitas-komunitas sepeda mini dapat berjualan dan memasarkan di Misu Store. (2) Penambahan informasi terkait sususan acara kegiatan di provinsi Jawa Timur agar semua komunitas mengetahui ada suatu acara dari komunitas yang menyelenggarakannya. (3) Pengembangan lebih lanjut berbasis Android.

\section{REFERENSI}

[1] Agus Mulyanto. Sistem Informasi Konsep dan Aplikasi. Yogyakarta. Pustaka Pelajar.

[2] Arief M Rudianto. 2011. Pemrograman Web Dinamis menggunakan PHP dan MySQL. Yogyakarta. C.V Andi Offset

[3] Ariona, R., 2013, Belajar HTML dan CSS "Tutorial Fundamental dalam Mempelajari HTML dan CSS, Ariona.net.

[4] Priyadi, Yudi. 2014. Kolaborasi SQL dan ERD Dalam Implementasi Database. Yogyakarta C.V Andi Offset

[5] Pahlevy 2010. Pengertian Flowchart dan definisi data 
Procedia of Engineering and Life Science Vol. 1. No. 2 Juni 2021

Seminar Nasional \& Call Paper Fakultas Sains dan Teknologi (SENASAINS 2nd)

Universitas Muhammadiyah Sidoarjo

(http://www.landasanteori.com/2015/10/pengertian-flowchart-dandefinisi-data.html)

[6] Scientific Journal of Informatics, 1(1), 53-63. http://doi.org/10.15294/sji.v1i1.3641 Nugroho, A. (2010). Rekayasa Perangkat Lunak Berbasis Objek dengan Metode USDP. Yogyakarta: Andi.

[7] Brady, M., \& Loonam, J. (2010). Exploring the use of entity-relationship diagramming as a technique to support grounded theory inquiry. Bradford: Emerald Group Publishing.

[8] Fatansyah. 2015. Basis Data. Bandung: Informatika Bandung

[9] Brady, M., \& Loonam, J. (2010). Exploring the use of Entity-relationship diagramming as a Technique to Support Grounded Theory Inquiry. Bradford: Emerald Group.

[10] Himawan, H., Saefullah, A., \& Santoso, S. (2018). Analisa dan Perancangan Sistem Informasi Penjualan Online (E-Commerce) pada CV Selaras Batik Menggunakan Analisis Deskriptif. 